\title{
A szelektív monoaminoxidáz-B-gátlók helye a Parkinson-kór kezelési stratégiájában a marosvásárhelyi ideggyógyászati klinikák gyakorlatában
}

\author{
Szász József Attila dr. ${ }^{1,2}$ - Constantin Viorelia dr. ${ }^{2}$ - Fazakas Péter Alpár ${ }^{1}$ \\ Blényesi Eszter ${ }^{1}$ - Grieb Levente Gábor ${ }^{1}$ - Balla Antal ${ }^{1}$ - Sárig Mónika ${ }^{1}$ \\ Szegedi Kinga ${ }^{1}$ - Bartha Eszter Noémi ${ }^{1}$. Szatmári Szabolcs dr. ${ }^{1,2}$ \\ ${ }^{1}$ Marosvásárhelyi Orvosi és Gyógyszerészeti Egyetem, Neurológiai Tanszék, Marosvásárhely, Románia \\ (University of Medicine and Pharmacy of Tirgu Mures, Department of Neurology, Tirgu Mures, Romania) \\ ${ }^{2}$ Marosvásárhelyi Megyei Sürgősségi Klinikai Kórház, 2. sz. Neurológiai Klinika, Marosvásárhely, Románia \\ (Tirgu Mures County Emergency Clinical Hospital, 2nd Clinic of Neurology, Tirgu Mures, Romania)
}

Bevezetés: A Parkinson-kór kezelési stratégiájában a szelektív monoaminoxidáz-B-gátlóknak a betegség minden stádiumában jól meghatározott helyük van. Enyhe esetekben, fóleg fiatal betegeknél, a szubsztitúciós terápia késleltetésének egyik hatékony eszközeként számolhatunk velük; előrehaladott Parkinson-kórban, a motoros komplikációk ellátásában, a levodopaterápia kiegészítői.

Célkitüzés: Annak felmérése, hogy a marosvásárhelyi ideggyógyászati klinikákon alkalmazott terápiás stratégiákban mekkora szerep jut a szelektív monoaminoxidáz-B-gátlóknak.

Módszer: Retrospektív tanulmányunkban 2003. január 1. és 2016. december 31. között a klinikákon vizsgált összes Parkinson-kóros beteg adatait elemeztük. A 2194 beteg zárójelentésében rögzített terápiás ajánlások alapján tanulmányoztuk a monoaminoxidáz-B-gátlók alkalmazásának sajátosságait. A Parkinson-kór megállapítása óta eltelt idő szerint öt éve, illetve több mint öt éve tartó betegségcsoportokat alkottunk.

Eredmények: A vizsgált időszakban az öt éve vagy ennél rövidebb ideje diagnosztizált csoportban 1183 betegből 243 esetben szerepelt a kezelési stratégiában monoaminoxidáz-B-gátló: 12 esetben monoterápia, 52 esetben dopaminagonistával, illetve 61 esetben levodopával kombinálva. A többi 118 betegnél levodopa és dopaminagonista kombinációjához társítva kerültek alkalmazásra a monoaminoxidáz-B-gátlók. A több mint öt éve ismert 582 esetből 195nél egészítették ki a terápiás stratégiát monoaminoxidáz-B-gátlóval (10 esetben szelegilin, 185 esetben rasagilin). Nem volt felhasználható adat a betegség kezdetét illetően 429 esetben (ezek közül öt esetben szelegilint, illetve 93 esetben rasagilint alkalmaztak).

Következtetés: A vizsgált periódusban a monoaminoxidáz-B-gátlók alkalmazásának aránya hasonló az irodalomban talált adatokhoz. A betegséggel foglalkozó szakorvosoknak nagyobb bátorsággal kellene alkalmazniuk a rendelkezésre álló és az ajánlásokban szereplő készítményeket, jobban kihasználni a különböző gyógyszertársítások előnyeit, különösen, ha ez nem terheli anyagilag a beteget.

Orv Hetil. 2017; 158(51): 2023-2028.

Kulcsszavak: Parkinson-kór, szelektív monoaminoxidáz-B-gátlók

The role of selective monoamine oxidase $B$ inhibitors in the therapeutic strategy of Parkinson's disease in the neurology clinics of Tirgu Mures County Emergency Clinical Hospital

Introduction: Selective monoamine oxidase B inhibitors have an accurate place in therapeutical strategy of Parkinsons's disease. In the early stages of the disease, especially in younger patients with milder symptoms, the introduction of levodopa substitution could be efficacious in delaying; in advanced stages they are mainly used to treat motor complications, as an adjunct to levodopa. 
Aim: The evaluation of therapeutical strategies used in the neurology clinics of Tirgu Mures County Emergency Clinical Hospital in order to define the role of monoamine oxidase B inhibitors.

Method: This retrospective study includes all records of patients with Parkinson's disease hospitalized between 1 January 2003 and 31 December 2016. From the 2194 reports we used data focusing on the therapeutic recommendations. Regarding disease duration, we divided the patients in two groups: less than or equal to 5 years and more than 5 years.

Results: From the 1183 patients in first group, 243 received monoamine oxidase inhibitors: 12 as monotherapy, 52 together with dopamine agonists, in 61 cases combined with levodopa. In 118 cases monoamine oxidase inhibitors were combined with levodopa and dopamine agonists. From 582 cases whith Parkinson's disease for more than 5 years, 195 received monoamine oxidase B inhibitors (selegiline: 10 cases, rasagiline: 185 cases). In 429 cases we did not find accurate data regarding disease duration (selegiline: 5 cases, rasagiline: 93 cases).

Conclusion: The use of monoamine oxidase B inhibitors was similar to those found in literature. The treating physicians should utilise more confidently the available therapeutical combinations.

Keywords: Parkinson's disease, selective monoamine oxidase B inhibitors

Szász JA, Constantin V, Fazakas PA, Blényesi E, Grieb LG, Balla A, Sárig M, Szegedi K, Bartha EN, Szatmári Sz. [The role of selective monoamine oxidase B inhibitors in the therapeutic strategy of Parkinson's disease in the neurology clinics of Tirgu Mures County Emergency Clinical Hospital]. Orv Hetil. 2017; 158(51): 2023-2028.

(Beérkezett: 2017. augusztus 19.; elfogadva: 2017. szeptember 9.)

\section{Rövidítések}

COMT $=$ katechol-O-metil-transzferáz; DA = dopaminagonista; $\mathrm{LD}=$ levodopa MAO-B = monoaminoxidáz-B; $\mathrm{MAO}-\mathrm{Bg}=$ monoaminoxidáz-B-gátlók; PK = Parkinson-kór

A Parkinson-kór a második leggyakoribb neurodegeneratív kórkép, amely a 65 év fölötti lakosság 1\%-át, míg a 85 év fölötti lakosság 5\%-át érinti [1]. Tekintettel az európai lakosság átlagéletkorának az utóbbi évtizedekben tapasztalható fokozatos emelkedésére, a kórkép incidenciájának növekedésével kell számolnunk. A betegség etiológiája 200 évvel a kórkép leírása után is ismeretlen, annak ellenére, hogy a betegséggel kapcsolatos egyéb ismereteink exponenciálisan növekedtek, és ezek új gyógyszeres és múszeres kezelési alternatívákat is eredményeztek. Oki kezelés hiányában, a terápiás törekvések a tünetek javítása mellett a levodopakezelés késői komplikációinak (motoros és nem motoros) késleltetésére, illetve enyhítésére fektetik a hangsúlyt. Nem elhanyagolható a betegség progressziójának lassítása sem, jóllehet, ennek a lehetőségnek az egyértelmű bizonyítékai is váratnak még magukra [2]. Parkinson-kórban a vezető biokémiai zavar a nigrostriatalis rendszer dopaminszintjének csökkenése. A dopaminerg homeosztázis korrigálásának klinikai szempontból is leghatékonyabb módja a levodopakészítményekkel történő szubsztitúciós terápia. A levodopakezelés megkezdése szigorúan egyénre szabott módon történik. Az idős (70 év feletti) Parkinsonkóros betegeknél a levodopaterápia bevezetésének nincs alternatívája. A fiatalabb (60 év alatti) korosztály esetében viszont a levodopa korai bevezetését mérlegelni kell. (A szubsztitúciós terápia bevezetésének halasztása ajánlott, a motoros komplikációk késleltetése végett.) Erre a célra kiválóan alkalmasak mind a dopaminagonisták (DA), mind a szelektív monoaminoxidáz-B- (MAO-B-) gátlók, illetve a két gyógyszercsoport kombinációi.

A mindennapos klinikai gyakorlatban három MAO-Bgátlót használnak: szelegilin, rasagilin és safinamid. A szelegilin, illetve a később kifejlesztett rasagilin szelektív és irreverzibilis MAO-B-gátlók, míg a safinamid komplex hatásmechanizmusa a szelektív, de reverzibilis MAO-Bgátlás mellett nem dopaminerg (glutamátfelszabadulást gátló) hatást is feltételez. Az egyes MAO-B-gátlók klinikai hatékonyságát (korai és előrehaladott Parkinson-kórban egyaránt) számos klinikai vizsgálat igazolta [3-7].

\section{Célkitüzés, módszer}

Célunk volt felmérni, hogy a marosvásárhelyi ideggyógyászati klinikákon alkalmazott terápiás stratégiákban mekkora szerep jut a szelektív MAO-B-gátlóknak.

Retrospektív tanulmányunkban a marosvásárhelyi ideggyógyászati klinikákon 2003. január 1. és 2016. december 31. között vizsgált összes Parkinson-kóros beteg adatait elemeztük. Az egyes korcsoportokban 2194 beteg zárójelentésében rögzített terápiás ajánlások alapján tanulmányoztuk a MAO-B-gátlók alkalmazásának sajátosságait a Parkinson-kór különböző stádiumaiban és típusaiban. A betegeket a családorvos javaslatára vagy ennek kihagyásával akár többször is megvizsgálta a járóbeteg-rendelőben dolgozó neurológus, ezután következett a klinikai kivizsgálás. Tanulmányunkból kizártunk minden olyan esetet, ahol a klinikai vagy paraklinikai adatok differenciáldiagnosztikai kétségeket vetettek fel (például kezdeti súlyos demencia vagy súlyos depresszió, képalkotó vizsgálatokkal kimutatott lacunaris elváltozások, vagy ha a levodopa csak terápiás próbaként került 
1. táblázat

Kórházi ellátásban részesült Parkinson-kóros betegek fontosabb adatai, illetve a MAO-B-gátlók gyakorisága a kezelési sémában

\begin{tabular}{ll}
\hline Teljes esetszám & $2194(100 \%)$ \\
$\quad$ Férfiak & $1039(47,4 \%)$ \\
Nók & $1155(52,6 \%)$ \\
\hline Átlagéletkor & \\
Teljes esetszám & 66,9 év \\
$\leq 5$ éve ismert a PK & 65,2 év \\
>5 éve ismert a PK & 66,7 év \\
A PK fennállásának ideje nem ismert & 72,8 év \\
\hline A PK diagnózisa óta eltelt idő & \\
$\leq 5$ év & $1183(53,9 \%)$ \\
>5 év & $582(26,5 \%)$ \\
Nem ismert & $429(19,6 \%)$ \\
\hline MAO-B-gátlók alkalmazási aránya & \\
Összesen & $535 / 2194(24,3 \%)$ \\
$\leq 5$ éve ismert PK & $243 / 1183(20,5 \%)$ \\
>5 éve ismert PK & $195 / 582(33,5 \%)$ \\
A PK fennállásának ideje nem ismert & $97 / 429(22,6 \%)$ \\
\hline
\end{tabular}

MAO-B = monoaminoxidáz-B; $\mathrm{PK}=$ Parkinson-kór

bevezetésre). A Parkinson-kór diagnózisa óta eltelt idő szerint öt éve, illetve több mint öt éve Parkinson-kórban szenvedő betegcsoportokat alkottunk.

\section{Eredmények}

A vizsgált időszakban 2194 Parkinson-kóros beteg részesült kórházi ellátásban. Fontosabb adataikat, illetve a MAO-B-gátlók gyakoriságát a kezelési sémában az 1 . táblázat szemlélteti. Többször beutalt betegeknél az első zárójelentésben szereplő terápiás ajánlásokat vettük figyelembe, illetve azt, ha a MAO-B-gátlókat adjuváns terápiaként kezdték alkalmazni. A diagnózis felállítása óta eltelt idő szerint a betegeket két csoportba osztottuk: öt év vagy annál rövidebb, illetve több mint öt év. A rendelkezésre álló adatokból 429 esetben, sajnos, nem sikerült a betegség kezdetét megbízható módon meghatározni. Az öt év vagy ennél rövidebb ideje kórismézett 1183 betegból 243 esetben szerepelt a kezelési stratégiában MAO-B-gátló: 12 esetben monoterápia formájában, 52 esetben dopaminagonistával, illetve 61 esetben levodopával kombinálva. A többi 118 betegnél levodopa és DA kombinációjához társítva kerültek alkalmazásra a MAO-B-gátlók (1. ábra). A másik csoport öt évnél régebbi 582 esetéből 195 esetben egészítették ki a terápiát MAO-B-gátlóval, 125 betegnél levodopa, illetve DA kombinációjához társítva (2. ábra). Az ismeretlen ideje diagnosztizált 429 Parkinson-kóros beteg közül öt esetben szelegilint, 92 esetben rasagilint adtak. Az alkalmazott MAO-B-gátlók csoportonkénti megoszlását a 3 . ábra szemlélteti.

\section{Megbeszélés}

Parkinson-kórban a terápiás törekvések a tünetek javítása mellett a levodopakezelés késői szövődményeinek késlel-

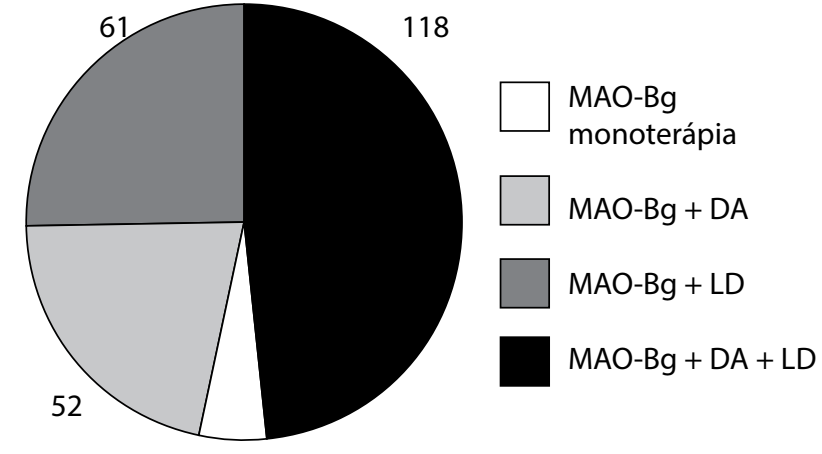

12

\begin{tabular}{l|l} 
1. ábra & Az öt éve vagy ennél kevesebb ideje kórismézett, szelektív mo-
\end{tabular} noaminoxidáz-B-gátlóval is kezelt Parkinson-kóros betegek kezelési sémája

$\mathrm{DA}=$ dopaminagonista LD = levodopa $\mathrm{MAO}-\mathrm{B}=$ monoamin oxidáz-B; MAO-Bg = monoaminoxidáz-B-gátlók; $\mathrm{PK}=$ Parkinson-kór

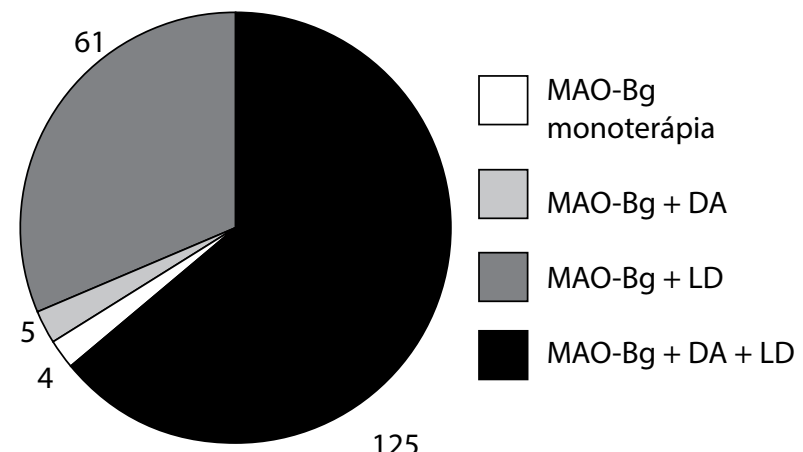

2. ábra $\quad$ A több mint öt éve kórismézett, szelektív monoaminoxidáz-B gátlóval is kezelt Parkinson-kóros betegek kezelési sémája

$\mathrm{DA}=$ dopaminagonista $; \mathrm{LD}=$ levodopa $; \mathrm{MAO}-\mathrm{B}=$ monoamin oxidáz- $\mathrm{B} ; \mathrm{MAO}-\mathrm{Bg}=$ monoaminoxidáz- $\mathrm{B}$-gátlók $\mathrm{PK}=$ Parkinson-kór

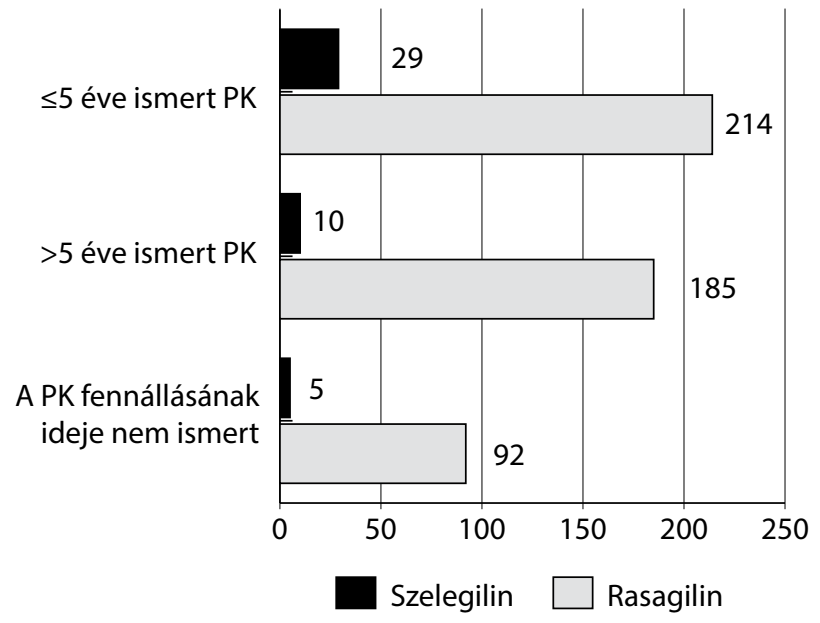

3. ábra $\mid \begin{aligned} & \text { Az alkalmazott szelektív monoaminoxidáz-B-gátlók megoszlása } \\ & \text { PK = Parkinson-kór }\end{aligned}$ 
tetésére, illetve enyhítésére fektetik a hangsúlyt. A betegséghez vezető legfontosabb biokémiai zavar a nigrostriatalis rendszer dopaminszintjének csökkenése. (A klinikai tünetek jelentkezésekor az érintett struktúrákban a dopaminszint már 20-30\%-ra csökken.) Mindez komplex, hosszú távon hatékony kompenzációs mechanizmusok egész sorára enged következtetni [8]. Ugyanakkor a klinikus számára is figyelmeztetés: a terápiás „beavatkozás” potenciálisan interferálhat, esetleg előnytelenül befolyásolhatja ezeket az (egyelőre csak részlegesen ismert) folyamatokat. A dopaminerg homeosztázis korrigálásának klinikai szempontból is leghatékonyabb módja a levodopakészítményekkel történő úgynevezett szubsztitúciós terápia (a kezelés „gold standard”-ja) [9]. A levodopakezelést szigorúan egyénre szabott módon kell beállítani a következő szempontok figyelembevételével: a beteg életkora a kórismézéskor, a funkciózavar mértéke, a kognitív státusz, az esetleges társpatológia és a gyógyszer okozta mellékhatások. A gyógyszer bevezetésének időpontjáról, illetve az optimális levodopaadagolásról (mind az egyszeri, mind a teljes napi adag, illetve az adagolási frekvencia) megoszlanak a vélemények. Az idős (70 év feletti) Parkinson-kórban szenvedő betegeknél enyhe kognitív hanyatlás és egyéb társbetegségek jelenlétében nem kétséges, hogy a levodopaterápia bevezetésének egyelőre nincs igazán alternatívája. A fiatalabb (60 év alatti) korosztály esetében viszont a korai levodopaterápiát alaposan mérlegelni kell. Ennél a korcsoportnál enyhe klinikai tünetek esetén a levodopa bevezetésének késleltetése ajánlott, a motoros komplikációk késleltetése végett. Erre a célra kiválóan alkalmasak mind a DA-k (napjainkban már kizárólag a nem ergotaminszármazékok), mind a szelektív MAO-B-gátlók, illetve a két gyógyszercsoport kombinációi. A jelenleg érvényes terápiás ajánlások a 65 éves kort határozzák meg „mérföldkőnek” a kezelési („levodopasporló”) stratégiák kidolgozásánál [9, 10]. Kevés irodalmi adatot találtunk a mindennapos klinikai gyakorlatban (real-life) alkalmazott terápiás stratégiákról. A 2013-ban közölt skandináv tanulmányban szignifikánsan gyakrabban alkalmazzák a szelegilint Norvégiában (23\%), mint Svédországban $(5 \%)$. A rasagilint az „egyebek” kategóriába sorolták (együtt a levodopa-carbidopa intestinalis géllel), tehát nem végezhető csoporton belüli összehasonlítás [11]. Az egyik kínai vizsgálatban a MAO-B-gátlókat a 65 évnél fiatalabb korban diagnosztizált betegek 10,3\%-ánál, míg a 65 év felettiek 3,3\%-ánál alkalmazták kezdeti monoterápiaként [12]. Hiányoznak továbbá az egyes készítményeket összehasonlító vizsgálatok is. Az izraeli lakosság negyedét felölelő, 2016-ban közölt tanulmányban a szelegilin-, illetve rasagilin-monoterápiával kezelt betegekben nem találtak szignifikáns különbséget a szubsztitúciós terápia bevezetéséig szükséges időtartamban [13]. A több mint 6000 Parkinson-kóros beteg adatait feldolgozó, de régebbi tanulmányban a szelegilin alkalmazási aránya 27,6\% volt Németországban, 2000-ben (értelemszerüen a rasagilint nem említik) [14]. Az újabb, 2017- es kínai tanulmányban a MAO-B-gátlók alkalmazásának alacsony, 16,38\%-os aránya magyarázataként egyértelmúen a magas költségeket jelölik meg [15]. Ha már a szubsztitúciós terápia bevezetése elkerülhetetlen (a mindennapi élet minőségének romlása egyértelmúvé válik), fontos szempont a lehető legkisebb hatékony levodopaadag használata. A kezelés legfontosabb korlátját a krónikus alkalmazást követően jelentkező motoros komplikációk - motoros teljesítményingadozások (fluktuációk) és dyskinesisek - jelentik [16]. Idővel a levodopa terápiás hatékonysága is csökken és a mellékhatások egyre gyakoribbak lesznek, ami az életminőség további romlását eredményezi. E hátrányokat hivatottak mérsékelni/késleltetni a dinamikusan változó terápiás ajánlások, és ezek felé irányulnak az új anti-Parkinson-szerekkel végzett klinikai vizsgálatok $[2,10,17]$.

A motoros komplikációk kialakulásának okait csak részben ismerjük: míg a motoros fluktuációk vélhetően a levodopa rövid felezési idejéhez (átlagban 90 perc) köthetőek, a dyskinesisek e hátrányos farmakokinetikai paraméteren túlmenően egy komplex, kóros plaszticitás végeredményeként jelentkeznek [16, 18]. A már említett kompenzációs mechanizmusok részletesebb megismerése megteremti az alapjait a motoros komplikációkat megelőző terápiás stratégiáknak. Többszintes (intrinszik) kompenzációs folyamattal állunk szemben: fokozódik a dopaminszintézis és -felszabadulás a még múködőképes sejtekből, ezzel párhuzamosan csökken a dopamininaktiválás. Csökken továbbá a dopamin-újrafelvétel (csökken a dopaminerg terminálok száma), ezáltal a dopaminmolekulák hosszabb ideig „aktívak” és nagyobb „távolságra” diffundálnak. A képet bonyolítja, a jelen ismereteink szerint, többnyire a szerotoninerg rendszerhez köthető „extraneuronalis” dopaminszintézis [8]. E komplex helyzetkép felismerésének másik fontos következménye az endogén (még meglévő) dopaminszint felértékelődése, illetve az exogén eredetú dopamin farmakodinámiás hatásának javítására való törekvés. A szelektív MAO-B-gátlók mindkét célra hasznos alternatívát jelenthetnek, és még a betegség előrehaladott stádiumaiban, az eszközös (device-aided) terápiák alkalmazása során is felírhatók [19]. A levodopánál, illetve a DA-nál gyengébb anti-Parkinson-hatásuk miatt viszont a mindennapos klinikai gyakorlatban elsősorban adjuváns terápiaként szerepelnek. Megítélésüket nem javítja számottevően a többi antiparkinsonikumhoz képest kedvezőbb mellékhatásprofil, illetve a vélhetően jobb terápiás adherencia sem, pedig ez utóbbi jelentőségét számos vizsgálat bizonyította. Elégtelen együttmúködés során romlik a betegek klinikai állapota, következésképpen mind a betegek, mind a hozzátartozók életminősége, továbbá növekednek az egészségügyi kiadások [2025]. A betegség korai stádiumában, amikor elég egyetlen hosszú hatástartamú dopaminagonista vagy MAO-Bgátló (esetleg ezek kombinációja), a betegek együttmüködése várhatóan a legnagyobb [26]. Vélhetően ez az 
egyik magyarázata a vizsgálatunk során tapasztalt jelentősen gyakoribb rasagilinalkalmazásnak (3. ábra).

$\mathrm{Az}$ általunk vizsgált periódusban csak minden negyedik beteg kezelési sémájában szerepelnek a MAO-B-gátlók, valamivel nagyobb arányban a betegség korai fázisaiban. Nem módosítja számottevően az összképet, hogy 21 betegnél dokumentálható volt a MAO-B-gátlók előzetes alkalmazása (kilenc esetben szelegilin, 12 esetben rasagilin), amelyek viszont „kiszorultak” a terápiából a levodopa bevezetésekor. A mindennapos klinikai gyakorlatban egyébként nem ritka megfigyelés, hogy a korai Parkinson-kórban alkalmazott MAO-B-gátló vagy DAmonoterápiát követően, amikor a klinikai kép súlyossága miatt elkerülhetetlen a levodopakezelés elkezdése, a kezelőorvos a levodopa-monoterápia mellett dönt, jóllehet, az említett, dopaminhiányt kompenzáló mechanizmusok, illetve a motoros komplikációk kialakulásának jobb megismerése inkább a kombinált terápia mellett szól $[4,7,16]$. Ugyanakkor nem lehet figyelmen kívül hagyni, hogy a klinikus gyakran, főleg idős betegeknél, a sokrétű társpatológia és az ennek megfelelő kezelés miatt a „leegyszerüsített” anti-Parkinson-terápiában a „legcsekélyebb hatékonyságú" készítményt mellőzi.

A vizsgált mintát reprezentatívnak ítéljük. Bár a romániai betegellátás szabályai szerint a Parkinson-kór kezelése térítésmentes, számos (drágábbnak ítélt) gyógyszer felírása csak a területileg illetékes szakmai bizottságok jóváhagyásával történhetett. Mindez azt is jelentette, hogy a területileg hozzánk tartozó minden olyan beteg vizsgálatra került, aki rasagilint, a dopaminagonisták közül rotigotintapaszt, illetve a katechol-O-metil-transzferáz- (COMT-) gátló entacapont (akár külön készítményt, akár levodopával kombinált bármilyen kiszerelést) kapott. Klinikai körülmények között történik természetesen az előrehaladott Parkinson-kóros betegek vizsgálata/követése a megfelelő invazív terápia kiválasztása céljából. Fontos szempont továbbá, hogy a Parkinson-kór kórismézése Romániában az ideggyógyász hatásköre, akárcsak a terápia elkezdése, illetve hatékonyságának követése. Ezzel szemben, a már említett skandináv tanulmányban, az esetek közel egynegyedében általános orvost, gerontológust vagy más területen dolgozó orvost neveztek meg [11]. Hasonló módon történik a kórismézés, illetve kezelés Izraelben a 2016-os cikk adatai szerint, azzal a pontosítással, hogy minél fiatalabb a beteg, annál nagyobb a valószínűsége, hogy neurológus vizsgálja meg [13].

Tanulmányunk erősségei közül kiemelnénk a nagy esetszámot és a vizsgált hosszú időtartamot, ami jobban tükrözi a mindennapi gyakorlatot, mint egy magas szelektivitású klinikai vizsgálat; a diagnózis pontosságát (egyetemi klinikára beutalt betegek, minden diagnózis, illetve kezelés mögött többszörös szűrő és neurológus „áll”); nem utolsósorban azt, hogy a gyógyszerek kiírását meghatározó szabályok miatt minden, rasagilinnel kezelt beteg szerepel az adatbázisban. Gyenge pontok: a tanulmány retrospektív jellege, sok az ismeretlen vagy hiányzó adat, és nem áll rendelkezésünkre nemzeti adatbázis, amihez a saját adatainkat viszonyítani lehetne, továbbá csak az adott pillanatban ajánlott kezelési stratégiát ismerjük, a hatásokat-mellékhatásokat nem lehetett követni.

\section{Következtetés}

A vizsgált periódusban a MAO-B-gátlók Parkinson-kórban történő felhasználási aránya hasonlít az irodalomban közölt adatokhoz. A betegséggel foglalkozó szakorvosoknak nagyobb bátorsággal kellene alkalmazniuk a rendelkezésre álló és az ajánlásokban szereplő készítményeket, különösen, ha ez nem terheli anyagilag a beteget. Kellő körültekintés mellett érdemes az életkorhoz is igazított kezelés során kihasználni a különböző gyógyszercsaládok előnyeit a megfelelő társításokban.

Anyagi támogatás: Studium-Prospero Alapítvány és az MTA közös pályázata: 138/2017.01.26 (Sz. J. A.) és részben: 0348/2016.02.26 (Sz. Sz.).

Szerzôi munkamegosztás: Sz. J. A., C. V., Sz. Sz.: Adatgyưjtés, elemzés, a közlemény megírása, szerkesztése. F. P. A., G. L. G., B. A.: Adatgyüjtés, elemzés. B. E., S. M., Sz. K., B. E. N.: Adatgyüjtés. A cikk végleges változatát valamennyi szerző elolvasta és jóváhagyta.

Érdekeltségek: Sz. J. A.: Tanácsadói/előadói tiszteletdíj: AbbVie, Novartis, Boehringer-Ingelheim, UCB Pharma, Lundbeck, GSK, Pfizer. C. V.: Előadói tiszteletdíj: AbbVie, UCB Pharma. A többi szerzőnek nincsenek érdekeltségeik.

\section{Köszönetnyilvánítás}

Köszönjük a következő kollégák segítségét: Szőcs Ildikó, Incze Emese, Lakatos Sándor, Varga Noémi Sára, Bordi László Lehel, Ráduly Dénes.

\section{Irodalom}

[1] De Lau LM, Breteler MM. Epidemiology of Parkinson's disease. Lancet Neurol. 2006; 5: 525-535.

[2] Dézsi L, Vécsei L. Monoamine oxidase B inhibitors in Parkinson's disease. CNS Neurol Disord Drug Targets 2017; 16: 425439.

[3] Olanow CW, Rascol O, Hauser R, et al. A double-blind, delayedstart trial of rasagiline in Parkinson's disease. N Engl J Med. 2009; 361: 1268-1278.

[4] Rascol O, Brooks DJ, Melamed E, et al. Rasagiline as an adjunct to levodopa in patients with Parkinson's disease and motor fluctuations (LARGO, Lasting effect in Adjunct therapy with Rasagiline Given Once daily, study): a randomised, double blind, parallel-group trial. Lancet 2005; 365: 947-954.

[5] Borgohain R, Szasz J, Stanzione P, et al. Randomized trial of safinamide add-on to levodopa in Parkinson's disease with motor fluctuations. Mov Disord. 2014; 29: 229-237. 
[6] Borgohain R, Szasz J, Stanzione P, et al. Two-year, randomized, controlled study of safinamide as add-on to levodopa in mid to late Parkinson's disease. Mov Disord. 2014; 29: 1273-1280.

[7] Waters CH, Sethi KD, Hauser RA, et al. Zydis selegiline reduces off time in Parkinson's disease patients with motor fluctuations: a 3-month, randomized, placebo-controlled study. Mov Disord. 2004; 19: 426-432.

[8] Schapira AH. Monoamine oxidase B inhibitors for the treatment of Parkinson's disease: a review of symptomatic and potential disease-modifying effects. CNS Drugs 2011; 25: 1061-1071.

[9] Ferreira JJ, Katzenschlager R, Bloem BR, et al. Summary of the recommendations of the EFNS/MDS-ES review on therapeutic management of Parkinson's disease. Eur J Neurol. 2013; 20: 5-15.

[10] Oertel W, Schulz JB. Current and experimental treatments of Parkinson disease: A guide for neuroscientists. J Neurochem. 2016; 139(Suppl 1): 325-337.

[11] Skogar Ö, Nilsson M, Törnhage CJ, et al. National surveys: a way to manage treatment strategies in Parkinson's disease? Pharmaceutical prescribing patterns and patient experiences of symptom control and their impact on disease. J Multidiscip Healthc. 2013; 6: 239-247.

[12] Li J, Chen D, Song W, et al. Survey on general knowledge on Parkinson's disease in patients with Parkinson's disease and current clinical practice for Parkinson's disease among general neurologists from Southwest China. Clin Neurol Neurosurg. 2014; 118: 16-20.

[13] Peretz C, Segev H, Rozani V, et al. Comparison of selegiline and rasagiline therapies in Parkinson disease: A real-life study. Clin Neuropharmacol. 2016; 39: 227-231.

[14] Möller JC, Körner Y, Dodel RC, et al. Pharmacotherapy of Parkinson's disease in Germany. J Neurol. 2005; 252: 926-935.

[15] Yang JX, Chen L. Economic burden analysis of Parkinson's disease patients in China. Parkinson's Dis. 2017; 2017: 8762939.

[16] Takats A, Nagy H, Radics P, et al. Treatment possibilities in advanced Parkinson's disease. [Kezelési lehetőségek a Parkinsonkór előrehaladott stádiumaiban.] Ideggyogy Sz. 2013; 66: 365371. [Hungarian]

[17] Borgohain R, Szasz J, Stanzione P, et al. First 2-year, controlled study to assess safinamide as add-on to levodopa in Parkinson's disease with motor fluctuations. Mov Disord. 2011; 26(Suppl 2): $120-121$
[18] Cattaneo C, Ferla RL, Bonizzoni E, et al. Long-term effects of safinamide on dyskinesia in mid- to late-stage Parkinson's disease. A post-hoc analysis. J Parkinsons Dis. 2015; 5: 475-481.

[19] Băjenaru O, Ene A, Popescu BO, et al. The effect of levodopacarbidopa intestinal gel infusion long-term therapy on motor complications in advanced Parkinson's disease: a multicenter Romanian experience. J Neural Transm. 2016; 123: 407-414.

[20] Haycox A, Armand C, Murteira S, et al. Cost effectiveness of rasagiline and pramipexole as treatment strategies in early Parkinson's disease in the UK setting. An economic Markov model evaluation. Drugs Aging 2009; 26: 791-801.

[21] Horstink M, Tolosa E, Bonuccelli U, et al. Review of the therapeutic management of Parkinson's disease. Report of a joint task force of the European Federation of Neurological Societies and the Movement Disorder Society-European Section. Part I: early (uncomplicated) Parkinson's disease. Eur J Neurol. 2006; 13: $1170-1185$.

[22] Kovacs N, Janszky J, Nagy F. Cost effectiveness of rasagiline and pramipexole as treatment strategies in early Parkinson's disease in the UK setting: An economic Markov model evaluation. Drugs Aging 2011; 28: 161-162.

[23] Lucza T, Karádi K, Komoly S, et al. Neurocognitive disorders in Parkinson's disease. [Neurokognitív zavarok diagnosztizálási és kezelési lehetőségei Parkinson-kórban.] Orv Hetil. 2015; 156 : 915-926. [Hungarian]

[24] Csóka M, Molnár S, Kellós É, et al. Problem solving care models of Parkinson's disease. [Problémamegoldó ápolási-gondozási modell Parkinson-kórban.] Orv Hetil. 2016; 157: 855-868. [Hungarian]

[25] Fülesdi B, Mitre C, Molnár C. Perioperative management of patients with Parkinson's disease. A survey literature. [Parkinsonkórban szenvedő betegek perioperatív ellátása. Irodalmi összefoglaló.] Orv Hetil. 2015; 156: 1355-1359. [Hungarian]

[26] Olanow CW, Kieburtz K, Leinonen M, et al. A randomized trial of a low-dose rasagiline and pramipexole combination (P2B001) in early Parkinson's disease. Mov Disord. 2017; 32: 783-789.

(Szatmári Szabolcs dr., 540081 Marosvásárbely, Gral Ion Dumitrache u. 20/2, Románia e-mail: szabolcs.szatmari@gmail.com)

\section{Felhívás előfizetésre}

Legyen Olvasónk a következő évben is!

Fizessen elő az Orvosi Hetilap 2018-as évfolyamára!

Egy füzet ára: $950 \mathrm{Ft}$.

Éves előfizetési díj: $39900 \mathrm{Ft}$, nyugdíjasoknak: $29925 \mathrm{Ft}$.

Az online változat éves előfizetési díja: $24990 \mathrm{Ft}$. 